\title{
Synthetic arylquinuclidine derivatives exhibit antifungal activity against Candida albicans, Candida tropicalis and Candida parapsilopsis
}

\author{
Kelly Ishida', Juliany Cola Fernandes Rodrigues², Simon Cammerer ${ }^{3}$, Julio A Urbina ${ }^{4}$, Ian Gilbert ${ }^{3}$, \\ Wanderley de Souza ${ }^{2,5}$, Sonia Rozental ${ }^{1 *}$
}

\begin{abstract}
Background: Sterol biosynthesis is an essential pathway for fungal survival, and is the biochemical target of many antifungal agents. The antifungal drugs most widely used to treated fungal infections are compounds that inhibit cytochrome P450-dependent C14 $\alpha$-demethylase (CYP51), but other enzymes of this pathway, such as squalene synthase (SQS) which catalyses the first committed step in sterol biosynthesis, could be viable targets. The aim of this study was to evaluate the antifungal activity of SQS inhibitors on Candida albicans, Candida tropicalis and Candida parapsilopsis strains.

Methods: Ten arylquinuclidines that act as SQS inhibitors were tested as antiproliferative agents against three ATCC strains and 54 clinical isolates of Candida albicans, Candida tropicalis and Candida parapsilopsis. Also, the morphological alterations induced in the yeasts by the experimental compounds were evaluated by fluorescence and transmission electron microscopy.

Results: The most potent arylquinuclidine derivative (3-[1'-\{4'-(benzyloxy)-pheny|\}]-quinuclidine-2-ene) (WSP1267) had a $\mathrm{MIC}_{50}$ of $2 \mu \mathrm{g} / \mathrm{ml}$ for all species tested and $\mathrm{MIC}_{90}$ varying from $4 \mu \mathrm{g} / \mathrm{ml}$ to $8 \mu \mathrm{g} / \mathrm{ml}$. Ultrathin sections of C. albicans treated with $1 \mu \mathrm{g} / \mathrm{ml}$ of WSP1267 showed several ultrastructural alterations, including (a) loss of cell wall integrity, (b) detachment of the plasma membrane from the fungal cell wall, (c) accumulation of small vesicles in the periplasmic region, (d) presence of large electron-dense vacuoles and (e) significantly increased cell size and cell wall thickness. In addition, fluorescence microscopy of cells labelled with Nile Red showed an accumulation of lipid droplets in the cytoplasm of treated yeasts. Nuclear staining with DAPI revealed the appearance of uncommon yeast buds without a nucleus or with two nuclei.
\end{abstract}

Conclusion: Taken together, our data demonstrate that arylquinuclidine derivatives could be useful as lead compounds for the rational synthesis of new antifungal drugs.

\section{Background}

Candidiasis is the most common fungal infection; it is found all over the world. Candida spp. isolates are the fourth most common microorganisms found in bloodstream infections and are particularly prevalent among patients hospitalised for long periods who have been exposed to antibiotics, immunosuppressive therapy,

\footnotetext{
* Correspondence: rozental@biof.ufrj.br

'Laboratório de Biologia Celular de Fungos, Instituto de Biofísica Carlos

Chagas Filho, Universidade Federal do Rio de Janeiro, Avenida Carlos Chagas Filho 373, Bloco C, Sala C0-026, Cidade Universitária, 21.941-902, Rio de Janeiro/RJ, Brazil

Full list of author information is available at the end of the article
}

parenteral nutrition, and multiple invasive medical procedures [1]. Systemic fungal infections are generally difficult to diagnose and hard to treat, having an attributable mortality rate of near $40 \%$ [1]. Although Candida albicans is the species most frequently isolated from those patients, being responsible for more than half of candidiasis cases, the incidence of other species, such as Candida parapsilopsis and Candida tropicalis, is increasing [2].

Most current therapies to treat fungal infections are based on disrupting fungal membrane homeostasis. The most commonly used groups of antifungal agents are

\section{Biomed Central}


the polyenes (e.g., amphotericin B), which disrupt membrane function by direct association with fungal sterols, and the azoles (fluconazole, itraconazole, voriconazole and posaconazole), which inhibit sterol biosynthesis in a step catalysed by the cytochrome P450-dependent C14 $\alpha$-demethylase [3]. Treatment of invasive Candida infections is often complicated by high toxicity, low tolerability or a narrow spectrum of activity of the current antifungal drugs as well as an increase in the incidence of azole-resistant strains [4]. These difficulties have driven the search for new treatments with different mode(s) of action.

Squalene synthase (SQS) is a key enzyme in sterol biosynthesis that catalyses an unusual head-to-head condensation of two molecules of farnesyl pyrophosphate in a two-step reaction to produce squalene, which is the first committed step in sterol biosynthesis. Importantly, inhibition of this enzyme does not affect the biosynthesis of other essential isoprenoids derived from farnesyl pyrophosphate derivatives, such as ubiquinones, dolichols, haeme, and $\mathrm{C}_{15^{-}}$or $\mathrm{C}_{20^{-}}$-isoprenoid chains [5]. In recent years, significant effort has been devoted to evaluating SQS with the aim of developing new cholesterol-lowering agents in mammalian cells [6]. Several classes of compound have been developed, including arylquinuclidines [7] and zaragozic acids. In addition, arylquinuclidine compounds have potent activity in concentrations varying from the nanomolar to subnanomolar range against parasitic protozoa, such as Trypanosoma cruzi, Leishmania and Toxoplasma gondii [8-12]. Zaragozic acids show significant activity against various fungal species [13].

In this work, the antifungal effect of the prototypical arylquinuclidine molecule BPQ-OH \{3-(biphenyl-4-yl)-3hydroxyquinuclidine or 3-biphenyl-4-yl-1-aza-bicyclo $[2,2,2]$-octan-3-ol\} and 9 derivatives was evaluated against three ATCC strains and 54 clinical isolates of C. albicans, C. parapsilosis and C. tropicalis. Five aspects of the antifungal effects of these compounds were investigated: (i) growth inhibition, (ii) fungicidal effect, (iii) morphological alterations, (iv) lipid accumulation and (v) cell cycle alteration.

\section{Methods}

\section{Drugs}

The prototypical arylquinuclidine BPQ-OH was prepared as described by Brown et al. [14]. Nine analogues (WSP1261, WSP1262, WSP1263, WSP1264, WSP1265, WSP1266, WSP1267, WSP1268 and WSP1269) (Figure 1) that are active against Leishmania major and selective to the parasite's SQS over the human enzyme [15] were also tested. Fluconazole, itraconazole, and amphotericin B were used as standard antifungal drugs. The compounds were diluted in DMSO, except fluconazole, which was diluted in water. They were then maintained at $-20^{\circ} \mathrm{C}$.

\section{Yeast collection}

To evaluate the antifungal activity of the synthetic arylquinuclidine derivatives, three standard strains from the American Type Culture Collection (ATCC) were used for screening: Candida albicans ATCC 10231, Candida parapsilosis ATCC 22019 and Candida tropicalis ATCC 13803. In addition, 54 clinical isolates of Candida were evaluated for high antifungal activity compounds: Candida albicans $(\mathrm{n}=21)$, Candida parapsilosis $(\mathrm{n}=19)$, and Candida tropicalis $(\mathrm{n}=14)$. These strains were isolated between 2002 and 2006 at the Microbiology/ Mycology Laboratory of Hemorio, Rio de Janeiro, Brazil, and kindly provided by Marcos Dornelas Ribeiro. The yeasts were maintained on Sabouraud dextrose agar at $4^{\circ} \mathrm{C}$, and subcultures were performed prior to each experiment in the same medium for $48 \mathrm{~h}$ at $35^{\circ} \mathrm{C}$.

\section{Antifungal activity assays}

Minimum inhibitory concentration (MIC) assays were performed using a broth microdilution method adapted from the M27-A3/CLSI document [16]. Briefly, each compound was diluted in RPMI 1640 medium (Sigma Chemical Co., Missouri, USA), buffered with MOPS $0.16 \mathrm{M}, \mathrm{pH} 7.0$, diluted in a 96-well microtitre tray and added to the growth medium to obtain the following final concentrations: $0.03-16 \mu \mathrm{g} / \mathrm{ml}$ (arylquinuclidines and itraconazole), $0.25-128 \mu \mathrm{g} / \mathrm{ml}$ (fluconazole) and $0.007-4 \mu \mathrm{g} / \mathrm{ml}$ (amphotericin B). Yeasts were then added to each well at the final concentration of $0.5-2.5 \times 10^{3}$ $\mathrm{cfu} / \mathrm{ml}$. The microtitre trays were incubated at $35^{\circ} \mathrm{C}$ for $48 \mathrm{~h}$ in a dark, humid chamber. Afterwards, $\mathrm{IC}_{50}$ values (the lowest concentrations that inhibit $50 \%$ of the yeast growth in comparison to control) for each compound were determined using a spectrophotometer at $492 \mathrm{~nm}$. To determine the trailing effect in Candida strains (persistent growth of some isolates of Candida in drug concentrations above the $\mathrm{IC}_{50}$ after $48 \mathrm{~h}$ of incubation, commonly observed in broth microdilution tests with azole agents) visual reading was performed after 24 and $48 \mathrm{~h}$ of incubation. $\mathrm{MIC}_{50}$ and $\mathrm{MIC}_{90}$ values (minimum inhibitory concentration required to inhibit the growth of $50 \%$ and $90 \%$ of the population of each Candida species with $n \geq 10$, respectively) were also determined for standard drugs. Only arylquinuclidine derivatives that showed antifungal activity lower than $16 \mu \mathrm{g} / \mathrm{mL}$ for ATCC strains were evaluated against the 54 clinical isolates. This breakpoint was selected because is the recommended concentration for the evaluation of new azoles without previously defined breakpoints [16].

Minimum fungicidal concentrations (MFC) were determined by transferring an aliquot $(10 \mu \mathrm{l})$ of each sample treated with concentrations higher than the $\mathrm{IC}_{50}$ onto a drug-free Sabouraud dextrose agar plate and incubated at $35^{\circ} \mathrm{C}$ for $48 \mathrm{~h}$. MFC means the lowest 


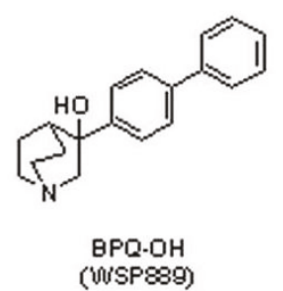

(U)SP\&89)

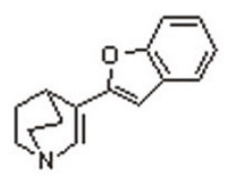

US SP1265<smiles>C[As](C)(C)Oc1ccc(C2=CN3CCC2C3)cc1</smiles>

UNSP1261

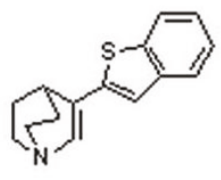

vi $\$ 1268$

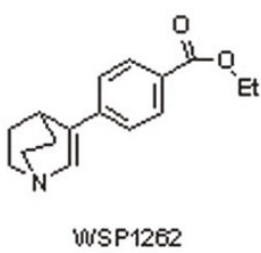<smiles>c1ccc(COc2ccc(C34CNCC(C3)C4)cc2)cc1</smiles>

WSP 1267<smiles>CC(C)OC(=O)c1ccc(C2=CN3CCC2CC3)cc1</smiles>

UNSP1263

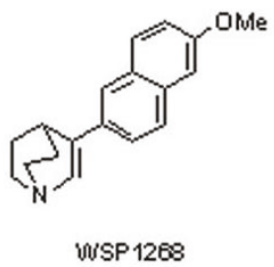

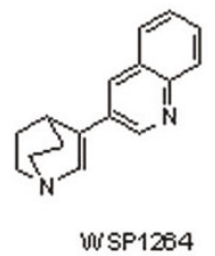

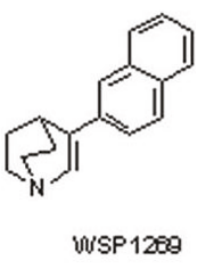

Figure 1 Molecular structures of the arylquinuclidine derivatives used in this work. The arylquinuclidine ring is indicated by an arrow.

concentration of compound that produces no fungal growth. A fungicidal effect was considered when the MFC value was equal to or up to four times the $\mathrm{IC}_{50}$ value. Above this value, the antifungal effect was considered fungistatic [17].

\section{Fluorescence microscopy}

C. albicans isolate 77 was chosen for all morphological analyses because this strain was susceptible to all standard antifungal drugs and had the median $\mathrm{IC}_{50}$ value for WSP1267 $(1 \mu \mathrm{g} / \mathrm{ml})$ of all the fungal populations tested. C. albicans isolate 77 untreated and treated with the $\mathrm{IC}_{50}$ of WSP1267 for $48 \mathrm{~h}$ at $35^{\circ} \mathrm{C}$ were washed in PBS, pH 7.2, fixed with $4 \%$ paraformaldehyde in PBS for $30 \mathrm{~min}$, adhered to glass coverslips, covered with poly-L-lysine and incubated with different fluorophores: (a) $5 \mu \mathrm{g} / \mathrm{ml}$ Nile Red (Fluka, USA), a fluorescent lipophilic stain, for $30 \mathrm{~min}$; or (b) $1 \mu \mathrm{g} / \mathrm{ml}$ DAPI (Sigma Chemical Co., Missouri, USA), a fluorescent stain that binds strongly to DNA, for $10 \mathrm{~min}$. The coverslips were then mounted in n-propyl gallate solution and observed under a Zeiss Axioplan epifluorescence microscope equipped with rhodamine (Nile Red fluorescence) and DAPI filters. Images were recorded on a C5810 Hamamatsu camera. The number of altered Candida was determined after counting at least 300 yeasts. To analyse the effects on the cell cycle, three morphological phases were considered: (I) cells with one nucleus, (II) cells with one bud (daughter cell) and one nucleus in the mother cell, and (III) cells with one bud and two nuclei (one in each cell).

\section{Transmission electron microscopy}

C. albicans isolate 77 untreated and treated with the $\mathrm{IC}_{50}$ of WSP1267 for $48 \mathrm{~h}$ at $35^{\circ} \mathrm{C}$ were fixed in a solution containing $2.5 \%$ glutaraldehyde and $4 \%$ freshly prepared formaldehyde in $0.1 \mathrm{M}$ cacodylate buffer $(\mathrm{pH}$ 7.2) for $1 \mathrm{~h}$. Then yeasts were post-fixed in $0.1 \mathrm{M}$ cacodylate buffer ( $\mathrm{pH} 7.2)$ containing $1 \%$ osmium tetroxide, $1.25 \%$ potassium ferrocyanide and $5 \mathrm{mM} \mathrm{CaCl}_{2}$ for 2 hours. After that, yeasts were serially dehydrated in ethanol and embedded in Spurr epoxy resin. Ultrathin sections were obtained with a Leica ultramicrotome, stained with uranyl acetate and lead citrate, and observed under a Zeiss CEM-900 electron microscope.

\section{Cytotoxicity assays}

Green monkey kidney (Vero) cells were used for the cytotoxicity assays. Cells were maintained in Dulbecco's Modified Eagle's Medium (DMEM, Gibco Invitrogen Corporation, New York, USA) supplemented with $2 \mathrm{mM}$ L-glutamine, $10 \%$ heat-inactivated foetal bovine serum (FBS), and $50 \mu \mathrm{g} / \mathrm{ml}$ gentamicin at $37^{\circ} \mathrm{C}$ in a $5 \% \mathrm{CO}_{2}$. For the experiments, Vero cells $\left(2.5 \times 10^{4}\right.$ cells/well $)$ were dispensed into a 96-well microtitre tray and incubated for $24 \mathrm{~h}$ to obtain a monolayer. Monolayers of Vero cells were treated with concentrations of WSP1267 varying from $1 \mu \mathrm{g} / \mathrm{ml}$ to $40 \mu \mathrm{g} / \mathrm{ml}$ for $48 \mathrm{~h}$ at $37^{\circ} \mathrm{C}$ in $5 \%$ $\mathrm{CO}_{2}$. The monolayers were fixed in $10 \%$ trichloroacetic acid for $1 \mathrm{~h}$ at $4^{\circ} \mathrm{C}$ and stained with sulphorhodamine $\mathrm{B}$ for $30 \mathrm{~min}$ at $4^{\circ} \mathrm{C}$. The optical densities were obtained in a spectrophotometer at $530 \mathrm{~nm}$ to calculate the $50 \%$ cytotoxic concentration $\left(\mathrm{CC}_{50}\right)$ [18].

\section{Statistical analysis}

Statistical analyses were performed with GraphPad Prism 5.0 (GraphPad Software), and $\mathrm{p}<0.05$ was considered significant. Student's t-test was used to analyse the morphological differences between untreated and 
treated yeasts. The frequency distribution of $\mathrm{IC}_{50}$ values was calculated to determine differences between the $\mathrm{MIC}_{50}$ and $\mathrm{MIC}_{90}$ values

\section{Results}

Antifungal activity

Among all quinuclidines tested, WSP1267 (3-[1'-\{4'-(benzyloxy)-phenyl\}]-quinuclidine-2-ene) exhibited the best anti-Candida effect, with $\mathrm{IC}_{50}$ varying from $0.5 \mu \mathrm{g} / \mathrm{ml}$ to $8 \mu \mathrm{g} / \mathrm{ml}$ (C. tropicalis ATCC 13803: $0.5 \mu \mathrm{g} / \mathrm{ml}$; C. albi-

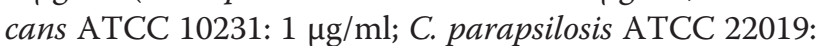
$8 \mu \mathrm{g} / \mathrm{ml}$ ). All other quinuclidine analogues tested on these three ATCC strains had $\mathrm{IC}_{50}$ values higher than $16 \mu \mathrm{g} / \mathrm{ml}$.

Afterwards, the anti-Candida effect of WSP1267 was evaluated against 54 Candida spp. clinical isolates (21 Candida albicans, 19 Candida parapsilosis and 14 Candida tropicalis). Although the $\mathrm{IC}_{50}$ values varied from $0.5 \mu \mathrm{g} / \mathrm{ml}$ to $16 \mu \mathrm{g} / \mathrm{ml}$ (Table 1 ), the $\mathrm{MIC}_{50}$ values (median value of each population) were the same for all tested Candida species $(2 \mu \mathrm{g} / \mathrm{ml})$. $\mathrm{MIC}_{90}$ values were 4 $\mu \mathrm{g} / \mathrm{ml}$ for $C$. parapsilosis, $8 \mu \mathrm{g} / \mathrm{ml}$ for C. albicans and $C$. tropicalis (Table 1). For this collection of strains, $C$. parapsilosis clinical isolates were more susceptible to WSP1267 and to standard antifungal agents, especially to itraconazole and amphotericin $\mathrm{B}$, than the other two species.

The MFC values for WSP1267 were higher than $16 \mu \mathrm{g} / \mathrm{ml}$ for all clinical isolates (data not shown), discounting any possibility of a fungicidal aspect of this drug.

All the clinical isolates showed similar susceptibility profile to amphotericin $\mathrm{B}\left(\mathrm{IC}_{50}\right.$ range of $\left.0.007-1 \mu \mathrm{g} / \mathrm{ml}\right)$. Two isolates of $C$. tropicalis were resistant to fluconazole, while 16 exhibited trailing effects (9 C. albicans, 4 C. tropicalis, and 3 C. parapsilosis). In addition, 4 isolates were resistant to itraconazole (3 C. tropicalis and 1 C. albicans), 6 isolates showed susceptibility in a dose-dependent manner (3 C. albicans, 2 C. tropicalis and 1 C. parapsilosis), and 11 isolates presented trailing effects (6 C. albicans, $4 \mathrm{C}$. tropicalis and 1 C. parapsilosis).

Remarkably, all isolates resistant to fluconazole ( $\mathrm{IC}_{50}$ $>64 \mu \mathrm{g} / \mathrm{ml})$ and itraconazole $\left(\mathrm{IC}_{50}>16 \mu \mathrm{g} / \mathrm{ml}\right)$ were susceptible to WSP1267 with a mean $\mathrm{IC}_{50}$ value of $8 \mu \mathrm{g} / \mathrm{ml}$.

\section{Morphological and ultrastructural effects}

Treatment of C. albicans with WSP1267 caused morphological and ultrastructural effects. Fluorescence microscopy of WSP1267-treated yeasts incubated with Nile Red revealed an accumulation of lipid droplets in the cytoplasm of treated yeasts when compared to C. albicans (isolate 77) control (Figure 2A-B), indicating that WSP1267 can induce the accumulation of lipids and/or precursors.
Table 1 Minimum inhibitory concentration of WSP1267, fluconazole, itraconazole and amphotericin B against 54 Candida spp. clinical isolates

\begin{tabular}{|c|c|c|c|c|}
\hline Drugs & $\begin{array}{l}\text { All species } \\
(\mathrm{n}=54)\end{array}$ & $\begin{array}{c}C . \\
\text { albicans } \\
(\mathrm{n}=21)\end{array}$ & $\begin{array}{c}C . \\
\text { parapsilosis } \\
(\mathrm{n}=19)\end{array}$ & $\begin{array}{l}\text { C. tropicalis } \\
(\mathrm{n}=14)\end{array}$ \\
\hline \multicolumn{5}{|l|}{ WSP1267 } \\
\hline Range & $0.5-16$ & $0.5-8$ & $0.5-8$ & $2-16$ \\
\hline $\begin{array}{r}\text { Geometric } \\
\text { mean }\end{array}$ & 2.54 & 2.2 & 2.46 & 3.32 \\
\hline $\mathrm{MIC}_{50}$ & 2 & 2 & 2 & 2 \\
\hline $\mathrm{MIC}_{90}$ & 8 & 8 & 4 & 8 \\
\hline \multicolumn{5}{|l|}{ Fluconazole } \\
\hline Range & $\begin{array}{l}<0.25 \text { to } \\
>128^{\mathrm{a}}\end{array}$ & $<0.25$ to 2 & $<0.25$ to 1 & $\begin{array}{l}<0.25 \text { to } \\
>128^{\mathrm{a}}\end{array}$ \\
\hline $\begin{array}{r}\text { Geometric } \\
\text { mean }\end{array}$ & 0.58 & 0.48 & 0.61 & 0.65 \\
\hline $\mathrm{MIC}_{50}$ & 0.25 & 0.25 & 0.5 & 0.5 \\
\hline $\mathrm{MIC}_{90}$ & 1 & 1 & 1 & 4 \\
\hline \multicolumn{5}{|l|}{ Itraconazole } \\
\hline Range & $\begin{array}{c}<0.03 \text { to } \\
>16^{\mathrm{b}}\end{array}$ & $\begin{array}{c}<0.03 \text { to } \\
0.5\end{array}$ & $<0.03$ to 0.5 & $\begin{array}{l}<0.03 \text { to } \\
>16^{\text {b }}\end{array}$ \\
\hline $\begin{array}{r}\text { Geometric } \\
\text { mean }\end{array}$ & 0.05 & 0.09 & 0.05 & 0.05 \\
\hline $\mathrm{MIC}_{50}$ & 0.03 & 0.03 & 0.03 & 0.03 \\
\hline $\mathrm{MIC}_{90}$ & 0.06 & 0.12 & 0.03 & 0.03 \\
\hline \multicolumn{5}{|l|}{$\begin{array}{l}\text { Amphotericin } \\
\text { B }\end{array}$} \\
\hline Range & $0.007-0.5$ & $0.007-0.25$ & $0.007-0.25$ & $0.007-0.5$ \\
\hline $\begin{array}{r}\text { Geometric } \\
\text { mean }\end{array}$ & 0.04 & 0.05 & 0.03 & 0.04 \\
\hline $\mathrm{MIC}_{50}$ & 0.03 & 0.03 & 0.03 & 0.06 \\
\hline $\mathrm{MIC}_{90}$ & 0.12 & 0.12 & 0.25 & 0.12 \\
\hline
\end{tabular}

(MIC values are expressed in $\mu \mathrm{g} / \mathrm{ml}$ ).

${ }^{a}$ Resistant (two C. tropicalis) and trailing effect (nine C. albicans, four C. tropicalis, and three C. parapsilosis).

${ }^{\mathrm{b}}$ Resistant (three $C$. tropicalis, one $C$. albicans), susceptibility dependence-dose (three C. albicans, two C. tropicalis and one C. parapsilosis) and trailing effect (six C. albicans, four C. tropicalis and one C. parapsilosis).

Treatment with the $\mathrm{IC}_{50}$ of WSP1267 induced alterations in the nuclear profile of $C$. albicans (Figure 3). The treatment induced a decrease of $34 \%(\mathrm{p}<0.05)$ in the number of yeasts presenting only one nucleus and no buds (phase I), an increase of three times $(\mathrm{p}<0.01)$ in the number of yeasts with buds lacking nuclei and only the mother cell having a nucleus (phase II) and an increase of three times in yeasts with one bud and two nuclei (one in each cell) (phase III), but not statistically significant. Labelling with DAPI also revealed abnormal chromatin condensation in approximately $11 \%$ of yeasts (Figure 4A, white arrow), while no nucleus was observed in $9 \%$ of yeasts (Figure $4 \mathrm{~B}$ ).

The morphological effects of the treatment with the $\mathrm{IC}_{50}$ of WSP1267 were also evaluated using transmission electron microscopy, which revealed that some organelles and structures could be potential targets for this 


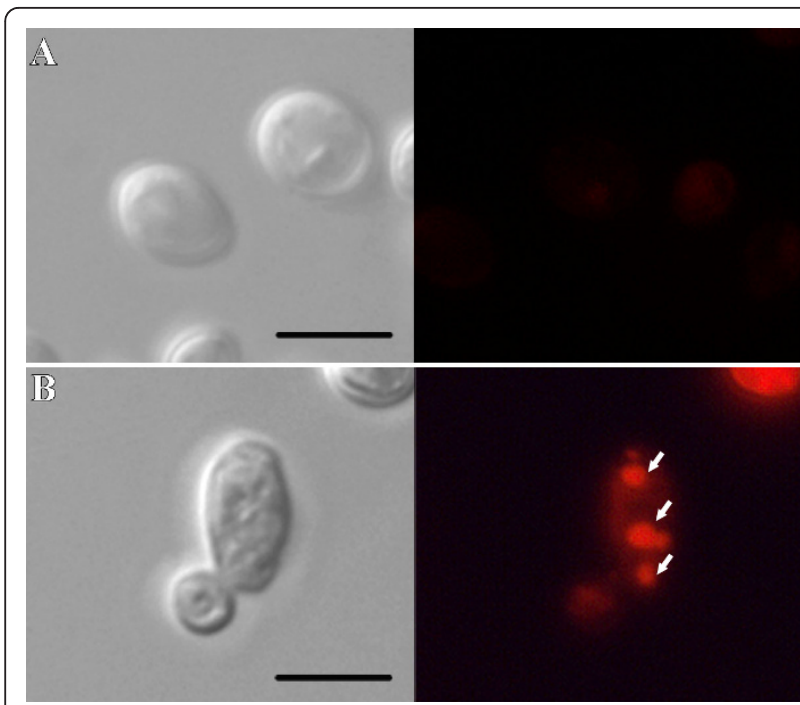

Figure 2 Differential interference contrast (DIC) microscopy (left) and fluorescence microscopy with Nile Red (right) of C. albicans (isolate 77) untreated (A) and treated with $1 \mu \mathrm{g} / \mathrm{ml} \mathrm{WSP1267}$

$\left[\mathrm{IC}_{50}\right]$ for $48 \mathrm{~h}$ at $35^{\circ} \mathrm{C}$ (B). The treatment induced an accumulation of lipid droplets in the cytoplasm of the yeasts (white arrows in B), which is not present in the untreated yeasts. Bars $=5 \mu \mathrm{m}$.

arylquinuclidine derivative. Ultrathin sections of untreated $C$. albicans showed well-preserved cells with an external fibrillar layer (f), a compact cell wall (cw), a plasma membrane with normal shape $(\mathrm{cm})$ and a homogeneous cytoplasm (Figure 5A). After the treatment, different ultrastructural alterations were observed, including (i) detachment of the plasma membrane from the cell wall (Figures 5B-C, asterisks), (ii) the presence of small vesicles in the periplasmic region (Figure $5 \mathrm{C}$, higher magnification in the inset), (iii) accumulation of large electron-dense vacuoles in the cytoplasm (Figure $5 \mathrm{D}, \mathrm{v}$ ), and (iiii) disruption of the cell wall (black arrow in Figure 5D). In addition, the loss of cell wall integrity was also observed in the bud (Figure 5B, black arrow). WSP1267 also induced a significant increase of cell size of C. albicans from $4.9 \pm 0.5 \mu \mathrm{m}$ (control cell) to $5.9 \pm$ $0.08 \mu \mathrm{m}$ (treated cell) $(\mathrm{p}<0.01)$ and cell wall thickness from $234 \pm 26 \mathrm{~nm}$ (control cell) to $303 \pm 87 \mathrm{~nm}$ (treated cell) $(\mathrm{p}<0.01)$.

\section{Cytotoxicity assays}

A $\mathrm{CC}_{50}$ of $12 \mu \mathrm{g} / \mathrm{ml}$ was observed in Vero cells treated with WSP1267.

\section{Discussion}

The incidence of fungal infections by Candida spp. in Brazilian medical centres is close to 2.5 cases per 1,000 admissions; the most prevalent species is C. albicans, followed by $C$. tropicalis and $C$. parapsilosis [1]. In addition, there is an important increase in the number of
Candida clinical isolates that are resistant to azoles, the most important class of drugs to treat fungal infections [1,19-21]. In our study, the percentage of fluconazoleresistant isolates $(3.7 \%)$ was lower than that observed in other studies on Brazilian clinical isolates (5.7\%) [1], isolates from North America (10.2\%) [19], and isolates from Europe (5.2\%) [20]. Pinto et al. [21] used 37 strains isolated from different anatomical sites of 11 immunocompromised hospitalised patients infected with HIV from the Hospital of the Federal University of Espírito Santo (ES, Brazil) and reported four Candida strains resistant to amphotericin B (10.8\%) and two to itraconazole (5.4\%). In our work, a higher incidence of itraconazole-resistant isolates (7.4\%) was observed, whereas all isolates were susceptible to amphotericin $B$, as shown in previous studies $[1,19,20]$.

Examples of recent approaches to antifungal treatments include new triazoles such as ravuconazole and albaconazole, which display a broad-spectrum activity against yeast and filamentous fungi, including species resistant to fluconazole and itraconazole [22]. In addition, the use of inhibitors from other steps of sterol biosynthesis is an alternative approach to the development of new chemotherapeutic agents. Several inhibitors of the mevalonate and isoprenoid pathways, as well inhibitors of the steps exclusively involved in ergosterol biosynthesis, have been studied against fungi [23] and parasitic protozoa [24]. For example, fluvastatin, a synthetic 3-hydroxy-3-methylglutaryl-coenzyme A reductase inhibitor, developed as a cholesterol-lowering agent, has a synergistic and fungicidal effect in combination with fluconazole and itraconazole against C. albicans, C. tropicalis, C. parapsilosis, and Cryptococcus neoformans, including fluconazole-resistant strains [25]. Inhibitors of sterol 24-methyltransferase, an enzyme that catalyses the incorporation of a methyl group at position 24 in the sterol side chain in fungi and trypanosomatids, has a potent effect against different clinical isolates of Candida spp. [26].

In the present work, we decided to investigate the effects of arylquinuclidine-based SQS inhibitors as a potential strategy for candidiasis treatment based on previous studies conducted with trypanosomatid parasites [24]. BPQ-OH was one of the first arylquinuclidines (originally developed as a potential cholesterol-lowering agent) reported to have potent activity against the Leishmania major SQS [27], blocking sterol biosynthesis and the growth of Leishmania spp. and T. cruzi in the lownanomolar to subnanomolar range [9-12,28]. However, BPQ-OH is not active against Candida spp. ATCC and clinical isolates. Therefore, we decided to test other derivatives that possessed a high activity and selectivity to the L. major enzyme over the human enzyme [15]. From the collection of arylquinuclidine compounds investigated in 


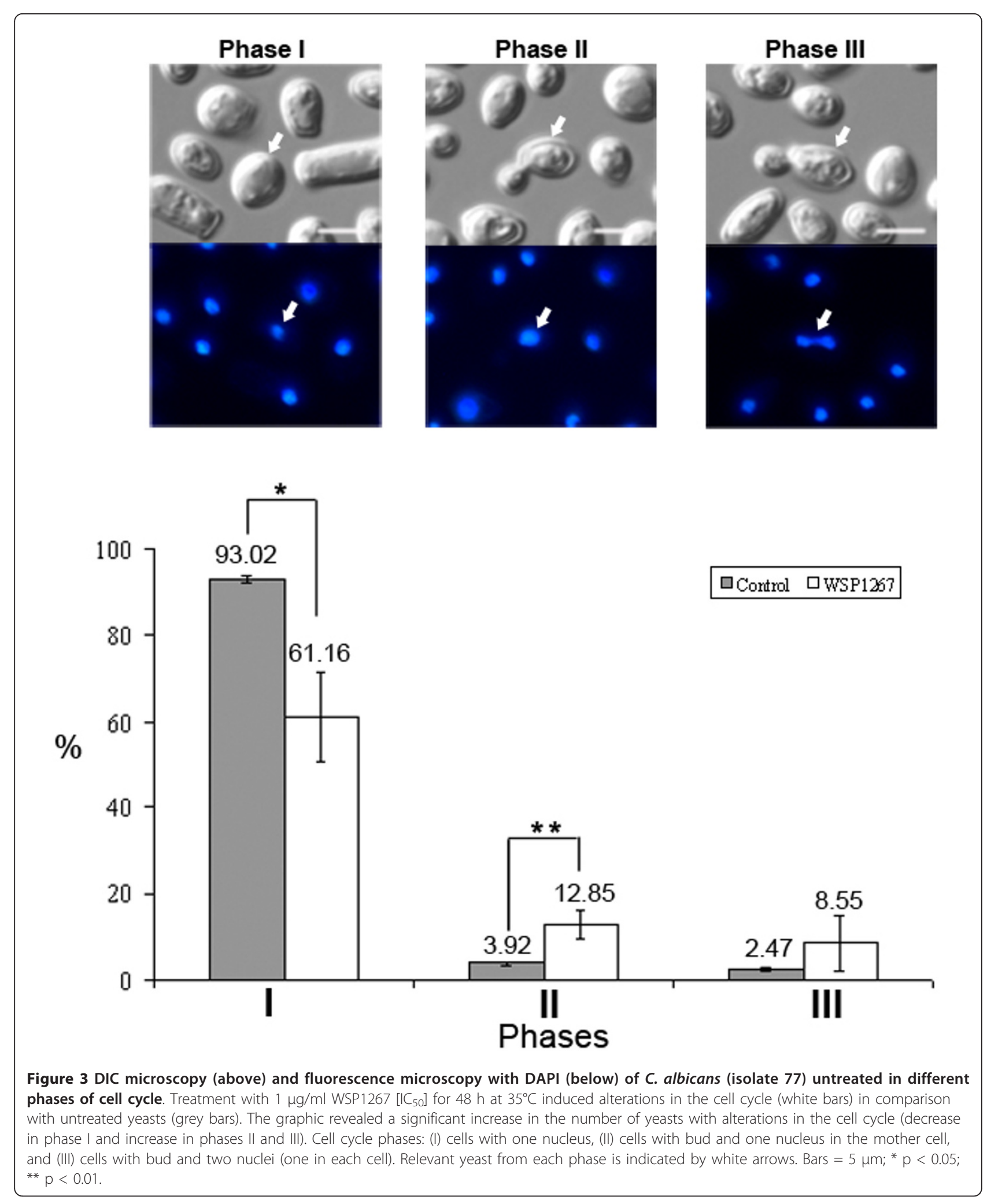



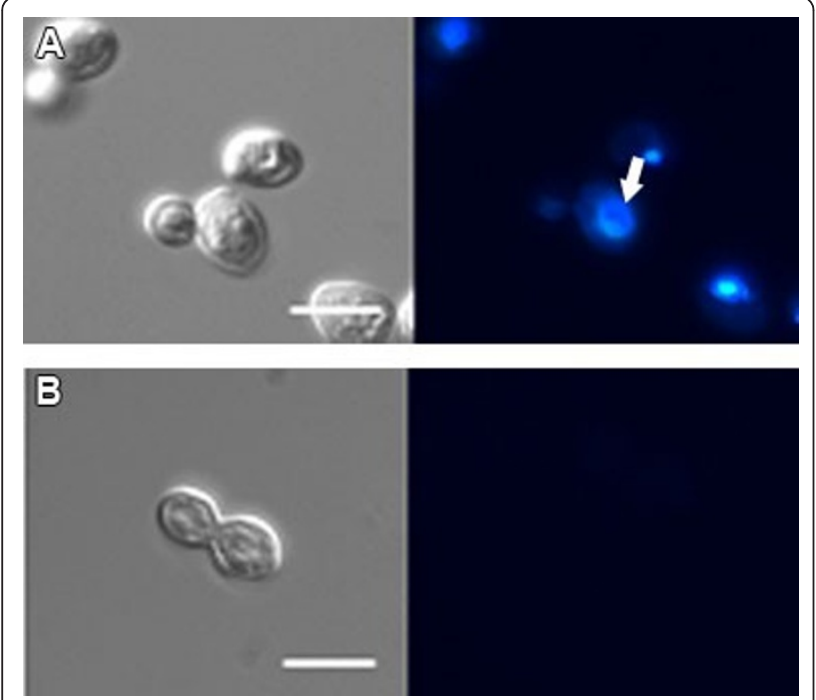

Figure 4 DIC microscopy (left) and fluorescence microscopy with DAPI (right) of $C$. albicans (isolate 77) treated with $1 \mu \mathrm{g} /$ $\mathrm{ml}$ of WSP1267 [IC $\left.\mathrm{C}_{50}\right]$ for $48 \mathrm{~h}$ at $35^{\circ} \mathrm{C}$, showing abnormal chromatin condensation ( $A$, white arrow) and absence of a nucleus (B). Bars $=5 \mu \mathrm{m}$.

this study, only WSP1267 showed activity against Candida spp. with $\mathrm{MIC}_{50}$ and $\mathrm{MIC}_{90}$ values of 2 and $4-8 \mu \mathrm{g} / \mathrm{ml}$, respectively. WSP1267 has also shown good potency against the Leishmania major SQS $\left(\mathrm{IC}_{50}=0.1 \mu \mathrm{M}\right)$ and activity against $L$. donovani parasites in cell culture $\left(\mathrm{EC}_{50}=\right.$ $1.1 \mu \mathrm{M})$ [15]. Cytotoxicity studies carried out with mammalian cells by Cammerer et al. [15] revealed that WSP1267 presents a 50\% cytotoxic concentration of 50\% $\left(\mathrm{CC}_{50}\right)$ of $13.7 \mu \mathrm{g} / \mathrm{ml}(47.2 \mu \mathrm{M})$ to L-6 cells. Our data using Vero cells to determine the cytotoxicity showed a similar value $(12.1 \mu \mathrm{g} / \mathrm{ml}$ or $41.6 \mu \mathrm{M})$.

To analyse morphological alterations, two different approaches were used in this work: (i) labelling of lipid droplets and DNA with specific fluorescent dyes (Nile red and DAPI, respectively); and (ii) visualisation of general ultrastructural alterations by transmission electron microscopy. The C. albicans 77 strain was chosen for all morphological analyses as a representative strain because it was susceptible to all standard antifungal drugs and presented the average WSP1267 $\mathrm{IC}_{50}$ value of all the fungal populations tested.

The presence of lipid droplets in the treated yeasts visualised by fluorescence microscopy using Nile Red (Figure 2) was correlated with the presence of electrondense vacuoles observed by electron microscopy (Figure 5), indicating that the quinuclidine treatment may induce an accumulation of lipid precursors in the cytoplasm which could be interfering directly with the fungal growth. These lipid droplets have also been observed after treatment of L. amazonensis with quinuclidine derivatives, due a total depletion of endogenous sterols and concomitant accumulation of exogenous cholesterol, which is not sufficient to maintain the viability of the parasites [10] Recently, our group has also shown a lipid accumulation in C. albicans clinical isolates after treatment with inhibitors of 24-sterol methyltransferase, another enzyme of the sterol biosynthesis pathway [26]. Moreover, previous studies show that it is also possible that quinuclidines interfere with fatty acid and phospholipid biosynthesis, as observed previously with mammalian cells treated with SQS inhibitors [29] and with the trypanosomatid Chritidia deanei after treatment with sterol 24-methyltransferase inhibitors [30].

Analyses of the effect of WSP1267 treatment on the C. albicans 77 isolate cell cycle revealed that the number of yeasts containing one nucleus (phase I) was significantly reduced, with a concomitant increase in the number of cells containing one bud and one nucleus (phase II) and yeasts containing one bud and two nuclei (phase III), in comparison with non-treated yeasts. There might be two possible explanations for these phenotypes: (i) the cells do not complete cell division due to alterations in the lipid composition, which is essential for membrane structure and also for control of the cell cycle; or (ii) the cells do not finish nuclear division, producing buds without nuclei. Taken together with the low MIC values and high MFC values, these data suggest that the action of WSP1267 was mostly fungistatic. Quinuclidine derivatives and 24-sterol methyltransferase inhibitors have similar effects on the cell cycle of L. amazonensis promastigotes [10] and Candida spp. [26]. Moreover, previous work has demonstrated that sterols control certain kinases involved in the cell cycle of yeasts [31]. Some images in this study suggested that the treated yeasts presented abnormal chromatin condensation, which is characteristic of apoptotic cell death. This is consistent with a previous study demonstrating that the deletion of the SQS gene in Saccharomyces cerevisiae leads to apoptotic cell death due to an impairment of ergosterol biosynthesis [32].

Transmission electron microscopy revealed important alterations in the integrity of the cell wall and plasma membrane, which could be related to depletion of essential endogenous sterols necessary to maintain their structures. The presence of small vesicles in the periplasmic region was also observed, as was the accumulation of large electron-dense vacuoles, which are consistent with the images taken by fluorescence microscopy. Similar morphological alterations have been reported in L. amazonensis treated with SQS inhibitors: an increase in the number of lipid inclusions displaying different shapes and electron densities, which were associated with an intense disorganisation of the cellular membrane [10,28]. Moreover, the important ultrastructural alterations observed in C. albicans treated with WSP1267 have been seen in 


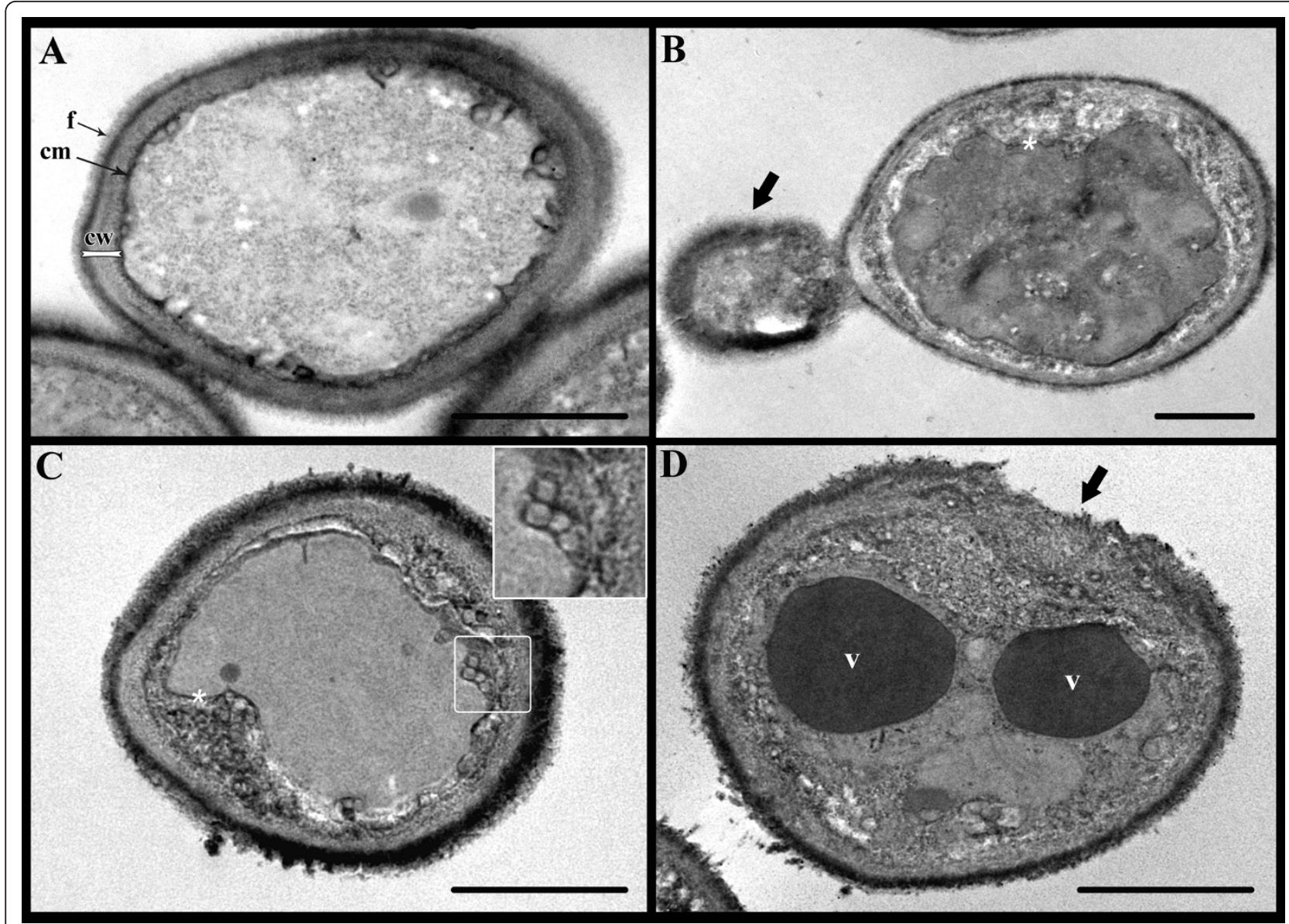

Figure 5 Ultrathin sections of $C$. albicans (isolate 77 ) control and treated with $1 \mu \mathrm{g} / \mathrm{ml}$ of WSP1267 [IC 50 for $48 \mathrm{~h}$ at $35^{\circ} \mathrm{C}$. Untreated yeast (A) present a preserved ultrastructure (fibrillar structures - $\mathrm{f}$, cytoplasm membrane - $\mathrm{cm}$, and compact cell wall - $\mathrm{CW}$ ). However, in treated yeasts (B-D), different alterations can be observed: disruption of cell wall and loss of cell wall integrity in the bud (B, black arrow), detachment of cytoplasmic membrane from the cell wall (B-C, arrow), presence of small vesicles in the periplasmic region (3B-D and inset in $3 C$ ) and large electron-dense vacuoles [v] (Figure 3D). Bars $=1 \mu \mathrm{m}$.

C. albicans treated with 24-sterol methyltransferase inhibitors [26] and are probably related to the impairment of ergosterol biosynthesis, as has been observed after treatment of L. amazonensis with other quinuclidine derivatives [10,28]. Additionally, previous work has shown that Candida spp. treated with azole agents present similar ultrastructural alterations under transmission electron microscopy [33-36]. Although only one C. albicans clinical isolate (77) was chosen to illustrate the morphological aspects caused by the use arylquinuclidine derivatives, others $C$. albicans and non-albicans strains, including those resistant strains to azoles, were also evaluated and similar morphological alterations were observed (data not shown).

\section{Conclusion}

Our results show that the arylquinuclidine derivative WSP1267 effectively inhibited the growth of a collection of Candida clinical isolates, including several azoleresistant strains, probably due to impaired sterol biosynthesis, which led to inhibition on cell growth and the accumulation of lipid precursors in the cytoplasm. Although the antifungal activity of WSP1267 seems to be due to SQS inhibition, further studies are needed to identify the molecular target of WSP1267 in yeasts. Additionally, we observed effects on the integrity of the cell wall and plasma membrane and effects on the cell cycle, which are essential for cell viability. These data warrant further investigation of arylquinuclidines as lead compounds for the rational synthesis of new, more effective antifungal agents with fewer toxic effects.

\section{Acknowledgements}

This work was supported by the Conselho Nacional de Desenvolvimento Científico e Tecnológico (CNPq) and Fundação Carlos Chagas Filho de Amparo à Pesquisa do Estado do Rio de Janeiro (FAPERJ). 


\section{Author details}

'Laboratório de Biologia Celular de Fungos, Instituto de Biofísica Carlos Chagas Filho, Universidade Federal do Rio de Janeiro, Avenida Carlos Chagas Filho 373, Bloco C, Sala C0-026, Cidade Universitária, 21.941-902, Rio de Janeiro/RJ, Brazil. ${ }^{2}$ Laboratório de Ultraestrutura Celular Hertha Meyer, Instituto de Biofísica Carlos Chagas Filho, Universidade Federal do Rio de Janeiro, Avenida Carlos Chagas Filho 373, Bloco C, Cidade Universitária, 21.941-902, Rio de Janeiro/RJ, Brazil. "'Welsh School of Pharmacy, Cardiff University, Redwood Building, King Edward VII Avenue, Cardiff, CF10 3XF, UK. ${ }^{4}$ Laboratorio de Química Biológica, Instituto Venezolano de Investigaciones Científicas, Caracas 1020, Venezuela. Instituto Nacional de Metrologia, Normalização e Qualidade Industrial-Inmetro, Avenida Nossa Senhora das Graças 50, 25250-020, Xerém, Duque de Caxias/RJ, Brazil.

\section{Authors' contributions}

$\mathrm{KI}$ carried out all experiments and data analysis. Kl, JCFR, JAU and SR participated in study design and manuscript writing. SC and IG collaborated in the synthesis of arylquinuclidine compounds. All authors have read and approved the final manuscript.

\section{Competing interests}

The authors declare that they have no competing interests.

Received: 18 June 2010 Accepted: 21 January 2011

Published: 21 January 2011

\section{References}

1. Colombo AL, Nucci M, Park BJ, Noue'R SA, Arthington-Skaggs B, Matta DA, Warnock D, Morgan J: Epidemiology of candidemia in Brazil: a nationwide sentinel surveillance of candidemia in eleven medical centers. J Clin Microbiol 2006, 44:2816-2823.

2. Kauffman CA: Fungal infections. Proc Am Thoracic Soc 2006, 3:35-40.

3. Odds FC, Brown AJP, Gow NAR: Antifungal agents: mechanisms of action. Trends in Microbiol 2003, 11:272-279.

4. Canuto MM, Rodero FG: Antifungal drug resistance to azoles and polyenes. Lancet Infect Dis 2002, 2:550-563.

5. Gonzalez-Pacanowska D, Arison B, Havel CM, Watson JA: Isopentenoid synthesis in isolated embryonic Drosophila cells. Farnesol catabolism and -oxidation. J Biol Chem 1988, 26:1301-1306.

6. Tavridou A, Manolopoulos VG: EP2300 compounds: focusing on the antiatherosclerotic properties of squalene synthase inhibitors. Curr Pharm Biotechnol 2009, 15:3167-3178.

7. McTaggart F, Brown GR, Davidson RG, Freeman S, Holdgate GA, Mallion KB, Mirrlees DJ, Smith GJ, Ward WH: Inhibition of squalene synthase of rat liver by novel 3'-sustituted quinuclidines. Biochem Pharmacol 1996, 51:1477-1487.

8. Martins-Duarte ES, Urbina JA, De Souza W, Vommaro RC: Antiproliferative activities of two novel quinuclidine inhibitors against Toxoplasma gondii tachyzoites in vitro. J Antimicrob Chemother 2006, 58:59-65.

9. Rodrigues JCF, Bernardes CF, Visbal G, Urbina JA, Vercesi AE, De Souza W: Sterol methenyl transferase inhibitors alter the ultrastructure and function of the Leishmania amazonensis mitochondrion leading to potent growth inhibition. Protist 2007, 158:447-456.

10. Rodrigues JCF, Concepcion JL, Rodrigues C, Caldera A, Urbina JA, De Souza W: In Vitro Activities of ER-119884 and E5700, Two Potent Squalene Synthase Inhibitors, against Leishmania amazonensis: Antiproliferative, Biochemical, and Ultrastructural Effects. Antimicrob Agents Chemother 2008, 52:4098-4114.

11. Urbina JA, Concepcion JL, Rangel S, Visbal G, Lira R: Squalene synthase as a chemotherapeutic target in Trypanosoma cruzi and Leishmania Mexicana. Mol Biochem Parasitol 2002, 125:35-45.

12. Urbina JA, Concepcion JL, Caldera A, Payares G, Sanoja C, Otomo T, Hiyoshi H: In Vitro and i Activities of E5700 and ER-11984884, Two Novel Orally Active Squalene Synthase Inhibitors, against Trypanosoma cruzi. Antimicrob Agents Chemother 2004, 2379-2387.

13. Bergstrom JD, Kurtz MM, Rew DJ, Amend AM, Karkas JD, Bostedor RG Bansal VS, Dufresne C, Vanmiddlesworth FL, Hensens OD, Liesch JM, Zink DL, Wilson KE, Onishi J, Milligan JA, Bills G, Kaplan L, Omstead MN, Jenkins RG, Huang L, Meinz MS, Quinn L, Burg RW, Kong YL, Mochales S, Mojena M, Martin I, Pelaez F, Diez MT, Alberts AW: Zaragozic acids-a family of fungal metabolites that are picomolar competitive inhibitors of squalene synthase. Proc Natl Acad Sci USA 1993, 90:80-84.

14. Brown GR, Clarke DS, Foubister AJ, Freeman S, Harrison PJ, Johnson MC, Mallion KB, McCormick J, MCTaggart F, Reid AC, Smith GJ, Taylor MJ: Synthesis and activity of a novel series of 3-biarylquinuclidine squalene synthase inhibitors. J Med Chem 1996, 39:2971-2979.

15. Cammerer SB, Jimenez $C$, Jones $S$, Gros L, Lorente SO, Rodrigues $C$, Rodrigues JCF, Caldera A, Perez LMR, De Souza W, Kaiser M, Brun R, Urbina JA, Pacanowska DG, Gilbert IH: Quinuclidine derivatives as potential antiparasitics. Antimicrob Agents Chemother 2007, 51:4049-4061.

16. Clinical and Laboratory Standards Institute: Reference method for broth dilution antifungal susceptibility testing of yeasts. Aproved standard CLSI document M27-A3. Clinical and Laboratory Standards Institute, Wayne, PA; 2008.

17. Pfaller MA, Sheehan DJ, Rex JH: Determination of Fungicidal Activities against Yeasts and Molds: Lessons Learned from Bactericidal Testing and the Need for Standardization. Clin Microbiol Rev 2004, 17:268-280.

18. Lin Z, Hoult J, Raman A: Sulforhodamine B assay for measuring proliferation of a pigmented melanocyte cell line and its application to the evaluation of crude drugs used in the treatment of vitiligo. $J$ Ethnopharmacol 1999, 66:141-150.

19. Ostrosky-Zeichner L, Rex JH, Pappas PG, Hamill RJ, Larsen RA, Horowitz HW, Powderly WG, Hyslop N, Kauffman CA, Cleary J, Mangino JE, Lee J: Antifungal susceptibility survey of 2,000 bloodstream Candida isolates in the United States. Antimicrob Agents Chemother 2003, 47:3149-3154.

20. Almirante B, Rodriquez D, Park BJ, Cuenca-Estrella M, Planes AM, Almela M, Mensa J, Sanchez F, Ayats J, Gimenez M, Saballs P, Fridkin SK, Morgan J, Rodriguez-Tudela JL, Warnock DW, Pahissa A: Epidemiology and predictors of mortality in cases of Candida bloodstream infection: results from population-based surveillance, Barcelona, Spain, from 2002 to 2003. $J$ Clin Microbiol 2005, 43:1829-1835.

21. Pinto PM, Weikert-Oliveira RCB, Lyon JP, Cury VF, Arantes RR, Koga-lto CY, Resende MA: In vitro antifungal susceptibility of clinical isolates of Candida spp. obtained from patients with different predisposing factors to candidosis. Microbiol Res 2008, 163:579-585.

22. Alves SH, Da Matta DA, Azevedo AC, Loreto ES, Boff E, Santurio JM, Guarro J: In vitro activities of new and conventional antimycotics against fluconazole-susceptible and non-susceptible Brazilian Candida spp. isolates. Mycoses 2006, 49:220-225.

23. Lóránd T, Kocsis B: Recent advances in antifungal agents. Mini Rev Med Chem 2007, 7:900-911.

24. De Souza W, Rodrigues JCF: Sterol Biosynthesis Pathway as Target for Anti-trypanosomatid Drugs. Interdiscip Perspect Infect Dis 2009, 2009:1-19.

25. Chin NX, Weitzman I, Della-Latta P: In Vitro Activity of Fluvastatin, a Cholesterol-Lowering Agent, and Synergy with Fluconazole and Itraconazole against Candida Species and Cryptococcus neoformans. Antimicrob Agents Chemother 1997, 41:850-852.

26. Ishida K, Rodrigues JCF, Ribeiro MD, Vila TVM, De Souza W, Urbina JA, Nakamura CV, Rozental S: Growth inhibition and ultrastructural alterations induced by $\Delta 24(25)$-sterol methyltransferase inhibitors in Candida spp. isolates, including non-albicans organisms. BMC Microbiol 2009, 9:74-85.

27. Lorente SO, Gomez R, Jimenez CJ, Cammerer S, Yardley V, de LucaFradley K, Croft SL, Ruiz-Perez LM, Urbina JA, Gonzalez-Pacanowska D, Gilber IH: Biphenylquinuclidines as inhibitors of squalene synthase and growth of parasitic protozoa. Bioorg Med Chem 2005, 13:3519-3529.

28. Rodrigues JCF, Urbina J, De Souza W: Antiproliferative and ultrastructural effects of $\mathrm{BPQ}-\mathrm{OH}$, a specific inhibitor of squalene synthase, on Leishmania amazonensis. Exp Parasitol 2005, 111:230-238.

29. Hiyoshi H, Yanachimachi M, Ito M, Yasuda N, Okada T, Ikuta H, Shinmyo D, Tanaka K, Kurusu N, Yoshida I, Abe S, Saeki T, Tanaka H: Squalene synthase inhibitors suppress triglyceride biosynthesis through the farnesol pathway in rat hepatocytes. J Lipid Res 2003, 44:128-135

30. Palmié-Peixoto I, Rocha MR, Urbina JA, De Souza W, Einicker-Lamas M, Motta MCM: Effects of sterol biosynthesis inhibitors on endosymbiontbearing trypanosomatids. Fems Microbiol Lett 2006, 255:33-42.

31. Dahl CE, Biemann HP, Dhal JS: A protein kinase antigenically related to pp60v-src possible involved in yeast cell cycle control: positive in vivo regulation by sterol. Proc Natl Acad Sci USA 1987, 84:4012-4016.

32. Jennings SM, Tsay YH, Fisch TM, Robinson GW: Molecular cloning and characterization of the yeast gene for squalene syntase. Proc Natl Acad Sci USA 1991, 88:6038-6042. 
33. Bellanger $P$, Nast CC, Fratti $R$, Sanati $H$, Ghannoum M: Voriconazole (UK109,496) inhibits the growth and alters the morphology of fluconazolesusceptible and -resistant Candida species. Antimicrob Agents Chemother 1997, 41:1840-1842.

34. Koul A, Vitullo J, Reyes G, Ghannoum M: Effects of voriconazole on Candida glabrata in vitro. J Antimicrob Chemother 1999, 44:109-112.

35. Borges M, Van de Ven MA: Degenerative changes after itraconzole treatment. Rev Infect Dis 1987, 9(Suppl 1):S33-42.

36. Hazen KC, Mandell G, Coleman E, Giangqin W: Influence of fluconazole at subinhibitory concentrations on cell surface hydrophobicity and phagocytosis of Candida albicans. FEMS Microbiology Letters 2000, 183:89-94.

doi:10.1186/1476-0711-10-3

Cite this article as: Ishida et al:: Synthetic arylquinuclidine derivatives exhibit antifungal activity against Candida albicans, Candida tropicalis and Candida parapsilopsis. Annals of Clinical Microbiology and Antimicrobials 2011 10:3.

\section{Submit your next manuscript to BioMed Central} and take full advantage of:

- Convenient online submission

- Thorough peer review

- No space constraints or color figure charges

- Immediate publication on acceptance

- Inclusion in PubMed, CAS, Scopus and Google Scholar

- Research which is freely available for redistribution

Submit your manuscript at www.biomedcentral.com/submit 